\title{
Estimation of leaf area in pecan cultivars (Carya illinoinensis)
}

\author{
Silvana Irene Torri ${ }^{1}$, Carla Descalzi ${ }^{1}$, and Enrique Frusso ${ }^{2}$ \\ ${ }^{1}$ Facultad de Agronomía, Universidad de Buenos Aires (FAUBA), Buenos Aires, Argentina. ${ }^{2}$ Instituto \\ Nacional de Tecnología Agropecuaria (INTA), Estación Experimental Delta del Paraná, Argentina.
}

\begin{abstract}
S.I. Torri , C. Descalzi, and E. Frusso. 2009. Estimation of leaf area in pecan cultivars (Carya illinoinensis). Cien. Inv. Agr. 36(1): 53-58. Nondestructive and mathematical approaches of modeling can be very convenient and useful for plant growth estimation. The objective of this research was to develop a simple, accurate and nondestructive predictive model for leaf area (LA) estimation in different pecan cultivars (Carya illinoinensis) commonly found in Argentina. Linear and exponential regression equations were fitted and evaluated for pecan cultivars 'Desirable', 'Harry Super', 'Kernodle', 'Mahan', 'Mahan-Stuart', 'Shoshoni', 'Stuart' and 'Success' (grafted on seedling pecan rootstocks, 24 years old, planted at 15 x 15 m) using length (L) and width (W) alternatively or both L and W in a stepwise analysis as nonforced independent variables. Stepwise regression analysis using $\mathrm{L}$ and $\mathrm{W}$ variables for each cultivar fitted the data better than $\mathrm{L}$ or $\mathrm{W}$ alone. A general equation for all cultivars showed high accuracy $\left(\mathrm{R}^{2}=0.93, \mathrm{p}<0.0001\right)$. However, for certain cultivars, the general equation provided lower precision than the model for each cultivar. Therefore, we conclude that LA can be estimated through the general or individual model for each cultivar.
\end{abstract}

Key words: Carya illinoinensis, leaf area, leaf length, leaf width, model, pecan.

\section{Introduction}

The knowledge of leaf area (LA) is essential to evaluate vegetative growth and to estimate crop production potential (Kozlowski et al., 1991), and, therefore, LA has been a subject of interest in different physiological studies and plant genetics. Because it is related to photosynthetic efficiency, it contributes to carbohydrate metabolism, dry matter accumulation, yield and quality (Williams, 1987; Centritto et al., 2000) of plant growth. The relationship between LA and fruit is very important in fruit crops; for example, it determines the nut size and filling in pe-

Received 18 March 2008. Accepted 21 August 2008. ${ }^{1}$ Corresponding author: torri@agro.uba.ar. cans (Carya illinoinensis). In addition, LA is an important factor for alternation (Sparks, 1974). In the cultivar 'Mohawk', it has been observed that a leaf:fruit ratio of 4 , an equivalent to a LA of $1150 \mathrm{~cm}^{2}$, produced better quality nuts than a leaf:fruit ratio of 2 (Marquard, 1987). In the cultivar 'Western', a leaf:fruit ratio of 2, equivalent to an LA of $575 \mathrm{~cm}^{2}$, was needed for nut filling (Marquard, 1987).

The total LA of a crop can be obtained from direct or indirect methods. Direct and destructive methods usually require removing leaves and then determining the LA using optical techniques, planimetry, photography, digital area integration and optical interceptometry. However, the high cost represented by the acquisition of the appropriate equipment hinders their use. On the contrary, indirect methods can supply a 
good LA estimation and are easy to use and less expensive than direct and nondestructive methods (Norman and Campbell, 1989).

Mathematical models are one of the most frequently indirect nondestructive methods used for LA estimation. The area of each leaf is closely related to length (L) and width (W), which may be described by regression equations. Thus, several investigators have found highly significant correlations between LA of grapevines and linear dimensions of the leaves, which allow for alternatives to the use of complex equipment and destructive samplings (Pire and Valenzuela, 1995; Gutierrez and Lavín, 2000; Williams and Martinson, 2003). The length $\mathrm{x}$ width relationship ( $\mathrm{L} \times \mathrm{W}$ ) was the better correlated variable to $L A\left(R^{2}=0.99\right)$ in the grapevines 'Chardonnay' and 'Chenin blanc' (Gutierrez and Lavín, 2000). Other studies using L or $\mathrm{W}$ leaf measurements have established regression equations to estimate the LA of cherry (Cittadini and Peri, 2006), kiwi (Mendoza-de Gyves et al., 2007), banana (Potdar and Pawar, 1991), and chestnut (Serdar and Demirsoy, 2006). In the pecan 'Western', a regression equation was used to calculate LA using the L $\mathrm{x}$ W relationship as an independent variable (Medina Morales, 1998). However, the developed regression models vary with the grapevine cultivars (Malevel and Weaver, 1974; Sepulveda and Kliewer, 1983). Therefore, the objective of this work was to develop a simple, precise, nondestructive and fast predictive model to estimate the LA for different pecan cultivars in full production in Argentina based on the leaflet's length and width.

\section{Materials and methods}

\section{Pecan orchard}

This study was performed in a pecan orchard located at the Experimental Station, Instituto Nacional de Tecnología Agropecuaria (INTA), Delta del Paraná $\left(34^{\circ} 08^{\prime} 42^{\prime}\right.$ ' S, $\left.58^{\circ} 12^{\prime} \mathrm{W}\right)$ in a udifluvent soil type. The annual mean temperatures fluctuated between 17.5 and $19.0^{\circ} \mathrm{C}$, with annual mean precipitations between 1065.6 and $1277.0 \mathrm{~mm}$. The pecan cultivars sampled were 'Desirable', 'Harry Super', 'Kernodle', 'Mahan', 'Mahan-Stuart', 'Shoshoni', 'Stuart' and 'Success', which were grafted on seedling pecan rootstocks, 24 years old, and planted at $15 \times 15 \mathrm{~m}$.

\section{Leaf sampling}

Sampling was made in full production plants in mid-December when leaves were completely developed. Peripheral leaves from the middle portion of shoots that developed during the same growing season were harvested. Leaves were taken from shoots in the middle of the tree canopy located in the four cardinal points (Silva and Rodríguez, 1995). Ten leaves were sampled from each cultivar, each with 11 to 13 leaflets. Because of the morphological differences presented by terminal leaflets (wide and lanceolate leaves), they were excluded from this study. Leaves were kept refrigerated in plastic bags until the determinations were made.

For each sample, the width (W) was measured in the medium part of the leaflet, and the length (L) was determined from the base to the apex of the leaflet lamina. The LA of each leaflet was determined with the help of a leaf meter (Li-Cor LI-3100, LI-COR, Inc., Lincoln, NB, USA).

\section{Design and statistical analysis}

The experiment was designed as completely randomized blocks with 10 replicates. The pecan cultivars were the treatments, and each leaf was considered as an experimental unit. The results were analyzed for variance (ANOVA), and the means were separated according to Tukey's multiple comparison test $(p<0.05)$. The homogeneity of variance was estimated according to the Bartlett test $(\mathrm{p}<0.05)$. Statistics 4.0.7, 2000, was used.

For each cultivar, the relationship between LA and the linear parameters (L and W) was studied through linear regression analysis $[\mathrm{y}(\mathrm{x})=$ $\mathrm{mx}+\mathrm{b}$ ], exponential regression analysis [y (x) 
$\left.=\mathrm{A} \mathrm{x}^{\mathrm{p}}\right]$ or discriminating regression analysis [ $\mathrm{y}\left(\mathrm{x}_{1}, \mathrm{x}_{2}\right)=\mathrm{m}_{1} \mathrm{x}_{1}+\mathrm{m}_{2} \mathrm{x}_{2}+\mathrm{b}$ ], where $\mathrm{x}=$ length (L), width (W) or L $\mathrm{x}$ W (only in the case of linear regression) and $\mathrm{y}=$ leaf area (LA).

\section{Results}

The exponential model best explained the relationship between LA and L (LA $=0.69 \mathrm{~L}^{1.48}, \mathrm{R}^{2}$ $=0.89, \mathrm{p}<0.00001)$ when the results obtained for the eight pecan cultivars were analyzed together (Table 1, Figure 1).

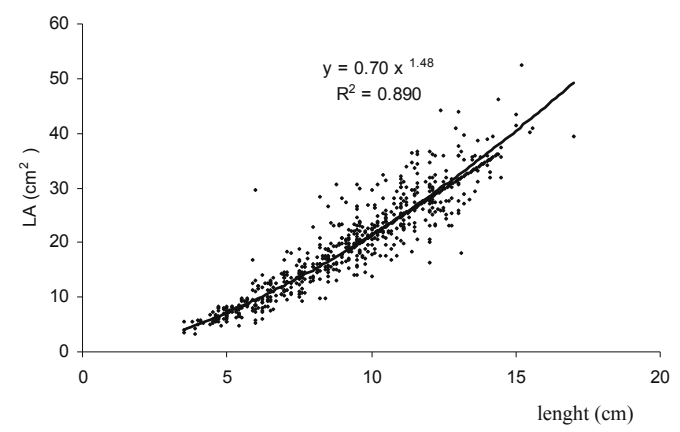

Figure 1. Relationship between leaf area (LA) and measurements of leaf length of eight pecan (Carya illinoinensis) cultivars analyzed together.

The relationship between LA and $\mathrm{W}$ was best explained using the linear model for pecan cultivars 'Desirable' and 'Stuart', whereas the LA and $\mathrm{W}$ relationship was best explained by the exponential model for 'Mahan-Stuart'. For the cultivars 'Harry Super', 'Kernodle', 'Mahan', 'Shoshoni' and 'Success', the LA was best estimated by linear or exponential regression equations. When using the results obtained for all the cultivars together, it was possible to estimate the LA linearly and exponentially (Table 1).

The variable $\mathrm{L} \times \mathrm{W}$ was well-correlated with LA in all the cultivars with determination coefficients of $\left(\mathrm{R}^{2}\right)>0.87$ and $\mathrm{p}<0.00001$, except for 'Desirable', which presented the lowest coefficient of determination $\left(\mathrm{R}^{2}=0.65, \mathrm{p}<0.00001\right)$. When results of all cultivars were analyzed together, the following model was obtained:

$\mathrm{LA}=1.95+0.60 \mathrm{~L} \times \mathrm{W} \quad \mathrm{R}^{2}=0.93, \mathrm{p}<0.00001$
The data obtained for each cultivar were analyzed through a discriminating analysis (stepwise analysis) using LA as a dependent variable and $\mathrm{L}$ and $\mathrm{W}$ as non-forced independent variables, retaining the variables contributing significantly $(p<0.001)$ to explain the variance observed (Table 2). The following equation was obtained by the discriminating analysis including the results of all the cultivars:

$\mathrm{LA}=-14.02+5.42 \mathrm{~A}+1.88 \mathrm{~L} \quad \mathrm{R}^{2}=0.93, \mathrm{p}<0.00001$

\section{Discussion}

The results obtained indicate that the use of regression equations using the leaflets $\mathrm{L}$ and/or $\mathrm{W}$ as independent variables to estimate the LA of pecan cultivars 'Desirable', 'Harry Super', 'Kernodle', 'Mahan', 'Mahan-Stuart', 'Shoshoni', 'Stuart' and 'Success' in full production is an accurate, nondestructive and fast alternative that could be very useful when integrated electronic equipment to determine these parameters is not available.

According to the linear or exponential regression analysis, the variables $\mathrm{L}$ and $\mathrm{W}$ presented separately a highly significant correlation $(\mathrm{p}<$ 0.00001 ) with LA in all the cultivars studied (Table 1). The use of $L$ as an independent variable had better results than using $\mathrm{W}$ independently. Using $\mathrm{W}$ as an independent variable produced lower coefficients of determination $\left(\mathrm{R}^{2}\right)$ and higher standard errors than using L.

For each cultivar, the models involving both variables presented higher coefficients of determination than the models involving only one variable (Table 2). The exception was with the cultivar 'Desirable', which presented low coefficients of determination $\left(0.64 \leq \mathrm{R}^{2} \leq 0.74\right)$ in all the models. The cultivar 'Success' presented a very high coefficient of determination in all the models $\left(\mathrm{R}^{2}=0.98\right.$, Tables 1 and 2$)$. The highest coefficients of determination corresponding to the models generated considering the width and length of the leaflets coincide with the coefficients reported for the pecan 'Western' (Medina Morales 1998), loquat (Portillo et al., 2004), lucumo (Simón and Trujillo de Leal, 
Table 1. Linear and exponential regression equations to estimate leaf area (LA) according to measurements of leaflet length (L) and width (W) of eight pecan (Carya illinoinensis) cultivars.

\begin{tabular}{|c|c|c|c|c|c|c|}
\hline \multirow[b]{2}{*}{ Pecan cultivars } & \multicolumn{6}{|c|}{ Leaf area $(\mathrm{LA})^{1}$ estimation: } \\
\hline & $\begin{array}{l}\text { Lineal } \\
\text { model } \\
\end{array}$ & $\mathrm{R}^{2}$ & SE & $\begin{array}{l}\text { Exponential } \\
\text { model }\end{array}$ & $\mathrm{R}^{2}$ & SE \\
\hline \multicolumn{7}{|l|}{ Leaflet $(L)$ length } \\
\hline Desirable & $\begin{array}{l}2.88 \mathrm{~L} \\
-7.27\end{array}$ & $0.74 * * *$ & 4.47 & $0.78 \mathrm{~L}^{1.43}$ & $0.74 * * *$ & 4.50 \\
\hline HarrySuper & $\begin{array}{l}2.95 \mathrm{~L} \\
-9.04\end{array}$ & $0.88 * * *$ & 3.01 & $0.66 \mathrm{~L}^{1.50}$ & $0.93^{* * *}$ & 2.50 \\
\hline Kernodle & $\begin{array}{l}2.88 \mathrm{~L}-7.93 \\
2.80 \mathrm{~L}-7.38\end{array}$ & $\begin{array}{l}0.83 * * * \\
0.84 * * *\end{array}$ & $\begin{array}{l}2.76 \\
3.59\end{array}$ & $\begin{array}{l}0.72 \mathrm{~L}^{1.46} \\
0.83 \mathrm{~L}^{1.40}\end{array}$ & $\begin{array}{l}0.83 * * * \\
0.84 * * *\end{array}$ & $\begin{array}{l}2.70 \\
3.60\end{array}$ \\
\hline Mahan-Stuart & $\begin{array}{l}3.99 \mathrm{~L} \\
-12.19\end{array}$ & $0.95^{* * *}$ & 2.69 & $0.68 \mathrm{~L}^{1.60}$ & $0.95^{* * *}$ & 2.60 \\
\hline $\begin{array}{l}\text { Shoshoni } \\
\text { Stuart }\end{array}$ & $\begin{array}{l}3.24 L-9.24 \\
3.14 L-9.06\end{array}$ & $\begin{array}{l}0.94 * * * \\
0.93 * * *\end{array}$ & $\begin{array}{l}2.47 \\
2.08\end{array}$ & $\begin{array}{l}0.74 \mathrm{~L}^{1.48} \\
0.56 \mathrm{~L}^{1.60}\end{array}$ & $\begin{array}{l}0.94 * * * \\
0.95 * * *\end{array}$ & $\begin{array}{l}2.50 \\
1.70\end{array}$ \\
\hline Success & $\begin{array}{l}3.37 \mathrm{~L} \\
-12.40\end{array}$ & $0.98 * * *$ & 1.07 & $0.54 \mathrm{~L}^{1.59}$ & $0.98^{* * *}$ & 1.10 \\
\hline All & $\begin{array}{l}3.11 \mathrm{~L} \\
-8.86\end{array}$ & $0.87 * * *$ & 3.33 & $0.69 \mathrm{~L}^{1.48}$ & $0.89 * * *$ & 2.90 \\
\hline Desirable & $\begin{array}{l}10.70 \mathrm{~W}- \\
11.78\end{array}$ & $0.77 * * *$ & 4.00 & $3.25 \mathrm{~W}^{1.66}$ & $0.64 * * *$ & 5.40 \\
\hline Harry Super & $\begin{array}{l}12.05 \mathrm{~W}- \\
16.07\end{array}$ & $0.85^{* * *}$ & 3.80 & $2.43 \mathrm{~W}^{1.88}$ & $0.85^{* * *}$ & 3.70 \\
\hline Kernodle & $\begin{array}{l}10.92 \mathrm{~W}- \\
12.15\end{array}$ & $0.78 * * *$ & 3.00 & $1.76 \mathrm{~W}^{2.20}$ & $0.79 * * *$ & 3.00 \\
\hline Mahan & $\begin{array}{l}12.92 \mathrm{~W}- \\
18.21\end{array}$ & $0.78 * * *$ & 4.20 & $1.76 \mathrm{~W}^{2.20}$ & $0.79 * * *$ & 4.10 \\
\hline Mahan-Stuart & $\begin{array}{l}10.94 \mathrm{~W}- \\
15.87\end{array}$ & $0.79 * * *$ & 3.40 & $3.46 \mathrm{~W}^{1.61}$ & $0.93 * * *$ & 3.23 \\
\hline Shoshoni & $\begin{array}{l}12.56 \mathrm{~W}- \\
20.17\end{array}$ & $0.86 * * *$ & 3.70 & $3.63 \mathrm{~W}^{-2.04}$ & $0.87 * * *$ & 3.53 \\
\hline Stuart & $\begin{array}{l}11.06 \mathrm{~W}- \\
15.64\end{array}$ & $0.92 * * *$ & 2.90 & $1.84 \mathrm{~W}^{2.00}$ & $0.88 * * *$ & 2.72 \\
\hline Success & $\begin{array}{l}11.45 \mathrm{~W}- \\
14.53\end{array}$ & $0.98 * * *$ & 0.99 & $3.01 \mathrm{~W}^{1.69}$ & $0.98 * * *$ & 1.03 \\
\hline All & $\begin{array}{l}11.07 \mathrm{~W}- \\
13.92\end{array}$ & $0.83^{* * *}$ & 3.70 & $2.60 \mathrm{~W}^{1.80}$ & $0.83^{* * *}$ & 3.60 \\
\hline
\end{tabular}

${ }^{1} \mathrm{R}^{2}=$ determination coefficient, $\mathrm{SE}=$ standard error of the estimation, $* * *=\mathrm{p}<0.00001$.

Table 2. Estimation of the leaf area (LA) of eight pecan (Carya illinoinensis) cultivars by linear regression equations using leaflet length $\mathrm{x}$ width $(\mathrm{L} \times \mathrm{W})$ and by stepwise analysis using $\mathrm{L}$ and $\mathrm{W}$.

\begin{tabular}{|c|c|c|c|c|c|c|}
\hline \multirow[b]{2}{*}{$\begin{array}{l}\text { Pecan } \\
\text { cultivars }\end{array}$} & \multicolumn{6}{|c|}{ Leaf area $(\mathrm{LA})^{1}$ estimation: } \\
\hline & $\begin{array}{l}\text { Lineal } \\
\text { model }\end{array}$ & $\mathrm{R}^{2}$ & SE & $\begin{array}{l}\text { Stepwise } \\
\text { model }\end{array}$ & $\mathrm{R}^{2}$ & SE \\
\hline Desirable & $3.65+0.57 \mathrm{~L} \mathrm{x} \mathrm{W}$ & $0.65 * * *$ & 5.21 & $-7.26+2.88 \mathrm{~L}^{2}$ & $0.74 * * *$ & 20.28 \\
\hline Harry Super & $1.14+0.62 \mathrm{Lx} \mathrm{W}$ & $0.98 * * *$ & 1.39 & $-14.98+5.29 \mathrm{~W}+2.00 \mathrm{~L}$ & $0.96^{* * *}$ & 2.90 \\
\hline Kernodle & $1.53+0.63 \mathrm{~L} \mathrm{x} \mathrm{W}$ & $0.96 * * *$ & 1.30 & $-14.95+6.05 \mathrm{~W}+1.77 \mathrm{~L}$ & $0.95 * * *$ & 2.40 \\
\hline Mahan & $1.07+0.63 \mathrm{~L} \mathrm{x} \mathrm{W}$ & $0.87 * * *$ & 3.21 & $-12.88+4.86 \mathrm{~W}+1.90 \mathrm{~L}$ & $0.87 * * *$ & 11.02 \\
\hline Mahan-Stuart & $1.75+0.62 \mathrm{~L} \mathrm{x} \mathrm{W}$ & $0.98 * * *$ & 1.61 & $-14.78+4.30 \mathrm{~W}+9.82 \mathrm{~L}$ & $0.97 * * *$ & 4.81 \\
\hline Shoshoni & $0.56+0.63 \mathrm{~L} \mathrm{x} \mathrm{W}$ & $0.98 * * *$ & 1.44 & $-15.00+4.63 \mathrm{~W}+2.23 \mathrm{~L}$ & $0.96 * * *$ & 3.50 \\
\hline Stuart & $0.91+0.62 \mathrm{Lx} \mathrm{W}$ & $0.98 * * *$ & 1.06 & $-13.60+4.54 \mathrm{~W}+2.07 \mathrm{~L}$ & $0.97 * * *$ & 2.00 \\
\hline Success & $3.28+0.55 \mathrm{~L} \mathrm{x} \mathrm{W}$ & $0.98 * * *$ & 1.00 & $-13.95+6.13 \mathrm{~W}+1.60 \mathrm{~L}$ & $0.99 * * *$ & 0.40 \\
\hline All & $1.95+0.60 \mathrm{~L} \mathrm{x} \mathrm{W}$ & $0.93 * * *$ & 2.45 & $-14.02+5.42 \mathrm{~W}+1.88 \mathrm{~L}$ & $0.93 * * *$ & 5.80 \\
\hline
\end{tabular}

${ }^{1} \mathrm{R}^{2}=$ determination coefficient, $\mathrm{SE}=$ standard error for the estimation, ${ }^{* * *}=\mathrm{p}<0.00001$.

${ }^{2}$ The variable $\mathrm{W}$ had $\mathrm{p}=0.0750$. 


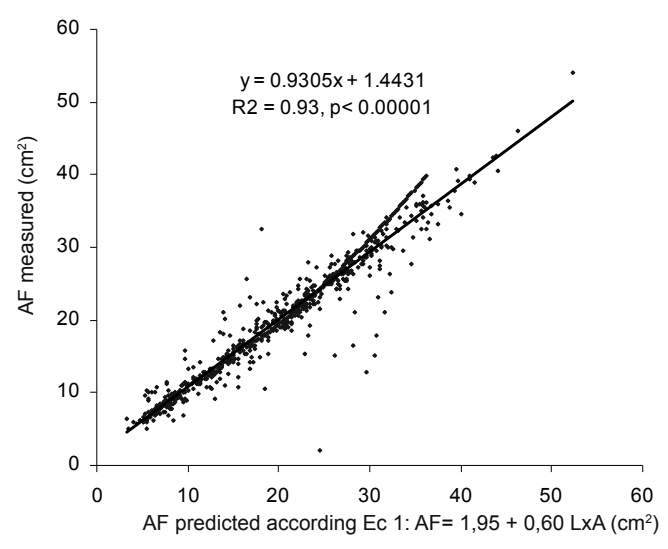

Figure 2. Relationship between measured and estimated leaf area (LA) for eight pecan (Carya illinoinensis) cultivars analyzed together using the regression model LA = $1.95+0.60 \mathrm{~L} \mathrm{x} \mathrm{A} \mathrm{(Eq} \mathrm{1).}$

1990), banana (Potdar and Pawar, 1991) and beans (Peksen 2007).

The two regression models (Eq 1 and Eq 2) each using data obtained for all pecan cultivars together had a high coefficient of determination, $\mathrm{R}^{2}=0.93$, so both models are statistically acceptable. However, in addition to the coefficients of determination $\left(\mathrm{R}^{2}\right)$, it is essential to evaluate the estimation capacity of the models through a comparison of the calculated values with real observed values (Figures 2 and 3). Although both equations were acceptable, Eq 2 ex-

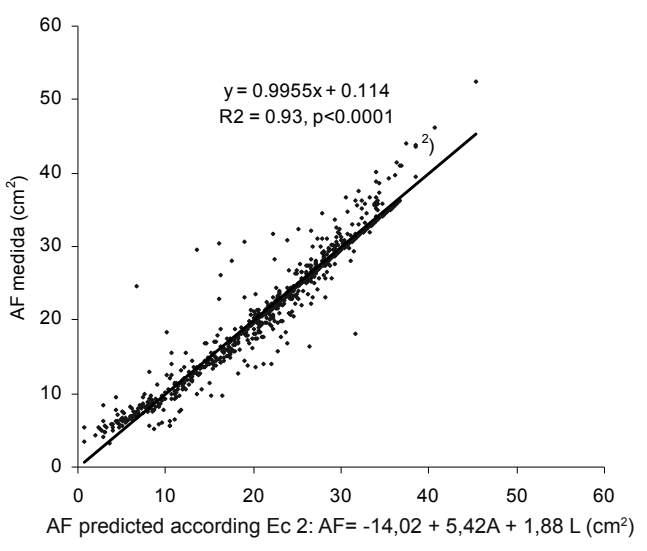

Figure 3. Relationship between measured and estimated leaf area (LA) for eight pecan (Carya illinoinensis) cultivars analyzed together using the regression model LA $=-14.02+$ $5.42 \mathrm{~A}+1.88 \mathrm{~L}(\mathrm{Eq} 2)$.

hibits close to a 1:1 linear slope and an ordinate close to zero (Chirinos et al., 1997). Therefore, the model Eq 2 is proposed for the LA estimation of the pecan cultivars studied. However, the general regression equation allows for a lower adjustment than the adjustments presented individually using the discriminating analysis for the cultivars 'Harry Super', 'Kernodle', 'Mahan-Stuart', 'Shoshoni', 'Stuart' and 'Success'. This indicates the need for using equations for each cultivar when a higher precision in estimation is required.

\section{Resumen}

S.I. Torri , C. Descalzi y E. Frusso. 2009. Estimación del área foliar en cultivares de pecán (Carya illinoinensis). Cien. Inv. Agr. 36(1): 53- 58. El conocimiento del área foliar (AF) es esencial para evaluar el crecimiento vegetal y estimar el potencial productivo de los cultivos. El objetivo de este trabajo fue desarrollar un modelo predictivo simple, preciso, no destructivo y rápido, para estimar el AF de distintos cultivares de pecán (Carya illinoinensis) en plena producción en Argentina basado en el largo (L) y ancho (A) de los folíolos. Se estudiaron ocho cultivares 'Desirable' 'Harry Super', 'Kernodle', 'Mahan', 'Mahan-Stuart' 'Shoshoni', 'Stuart' y 'Success', injertados sobre un patrón franco de pecán, de 24 años de edad, plantados a 15 x $15 \mathrm{~m}$. Se obtuvo una significativa correlación entre el L o A y el AF de los folíolos. Las mejores correlaciones para cada cultivar se obtuvieron a partir de un análisis discriminante, considerando como variables independientes no forzadas el L y A de cada foliolo. Se propone una ecuación general para el cálculo del AF de todos los cultivares. Sin embargo, para ciertos cultivares la ecuación general permitió un menor ajuste que la presentada para el respectivo cultivar. Se concluye que, según la precisión deseada, puede adoptarse la ecuación general para todos los cultivares o la ecuación particular para cada cultivar.

Palabras clave: Area foliar, Carya illinoinensis, nogal pecadero, pecán. 


\section{References}

Centritto M., Loreto F., Massacci A., Pietrini F., Villani M.C., and M. Zacchine. 2000. Improved growth and water use efficiency of cherry saplings under reduced light intensity. Ecol. Res. 15:385-392.

Chirinos D.T., Chirinos-Torres L., F. Geraud-Pouey, O. Castejón, R. E. Fernández, J.A. Vergara, L. E. Mármol, and D. Chirinos-Torres. 1997. Modelos para estimar el área foliar de melón híbrido 'Durango' .Revista de la Facultad de Agronomía (LUZ) (Venezuela) 14:163-171.

Cittadini, E.D., and P.L. Peri. 2006. Estimation of leaf area in sweet cherry using W non-destructive method. Revista de Investigaciones Agropecuaria (Argentina) 35:143-150.

Gutierrez T., A., and A. Lavín. 2000. Mediciones lineales en la hoja para la estimación no destructiva del área foliar en vides cv. Chardonnay. Agricultura Técnica (Chile) 60:69-73.

Kozlowski, T.T., P.J. Kramer y S.G. Pallardy. 1991. The Physiological Ecology of Woody Plants. Academic Press, San Diego. 657 pp.

Marquard, R.D. 1987. Influence of leaf to fruit ratio on nut quality, shoot carbohydrates, and photosynthesis of pecans. HortScience 22:256-257.

Medina Morales, C. 1998. Estimación de área foliar de folíolos en nogal pecadero. Revista Ciencia Agropecuaria (Argentina) 8:13-16.

Mendoza-de Gyves, E., Y. Rouphael, V. Cristofori, and F.R. Mira. 2007. A non-destructive, simple and accurate model for estimating the individual leaf area of kiwi (Actinidia deliciosa). Fruits 62:171-176.

Norman, J.M., and G.S. Campbell. 1989. Canopy structure. Pages 301-325. In: Plant Physiological Ecology: Field Methods and Instrumentation, R. Pearcy, J.R. Ehleringer, H.A. Mooney, and P.W.
Rundel (eds.). Chapman and Hall, London, UK.

Peksen, E. 2007. Non-destructive leaf area estimation model for faba bean (Vicia faba L.). Scientia Horticulturae 113:322-328

Pire, R., and I. Valenzuela. 1995. Estimación del área foliar en Vitis vinifera L. 'French Colombard'a partir de mediciones lineales en las hojas. Agronomía Tropical 45:143-154.

Portillo, A., M. Marín, R. Razz, and L. Sandoval. 2004. Estimación del área foliar de tres cultivares de níspero (Manilkara achras [Millar] Fosberg), bajo condiciones de bosque seco tropical. Rev. Fac. Agron. 21 (Supl. 1): 83-90.

Potdar, M.V., and K.R. Pawar. 1991 Non-destructive leaf area estimation in banana. Scientia Horticulturae 45:251-254.

Serdar, U., and H. Demirsoy. 2006. Non-destructive leaf area estimation in chestnut. Scientia Horticulturae 108:227-230.

Silva, H., and J. Rodriguez. 1995. Fertilización de plantaciones frutales. Ediciones Pontificia Universidad Católica de Chile. Santiago, Chile. 519 pp.

Simón, M. y A. Trujillo de Leal. 1990. Determinación del área foliar en cinco clones de lúcumo (Xanthosoma sagittifolium (L.) O. Schott) Revista de la Facultad de Agronomía (Maracay, Venezuela) 16:147158.

Sparks, D. 1974. The alternaye fruit bearing problem in pecans. Pages $145-157$. In: $65^{\text {th }}$ Annual Report of the Northern Nut Growers Association.

Williams III, L., and T.E. Martinson. 2003. Nondestructive leaf area estimation of 'Niagara' and 'De Chaunac' grapevines. Horticultural Science 98:493-498.

Williams, L.E. 1987. Growth of "Thompson Seedless" grapevines: I. Leaf area development and dry weight distribution. J. Amer. Soc. Hort. Sci. 112:325-330. 